\title{
Geographic distribution and morphological variation in Mimon bennettii (Chiroptera, Phyllostomidae)
}

\author{
Renato Gregorin ${ }^{1}$, Guilherme L. Capusso² \& Vanessa R. Furtado ${ }^{3}$
}

1. Departamento de Biologia, Universidade Federal de Lavras. Caixa Postal 3037, 37200-000 Lavras, MG, Brazil. (rgregorin@ufla.br)

2. Universidade Estadual Paulista, UNESP-IBILCE. São José do Rio Preto, SP, Brazil. (guilaraia@bol.com.br)

3. Universidade Federal de Uberlândia, Uberlândia, MG, Brazil.

\begin{abstract}
We studied discrete and quantitative data from 88 specimens of the subgenus Mimon previously identified as Mimon bennettii (Gray, 1838) and M. cozumelae Goldman, 1914 from diverse parts of their range. Our data indicate that specimens of Mimon bennetii in Brazil presented geographic variation in morphometrical characters and mosaic variation in qualitative traits. Specimens from the Cerrado biome collected in Brazilian states like Piaui, Tocantins, and Goiás have longer forearms than those distributed in the Atlantic and Amazon forested domains. Based on morphometrics, as showed by t-tests, specimens of M. bennettii from the Brazilian Cerrado resemble phenetically more with $M$. cozumelae than the $M$. bennettii from Atlantic Forest. Characters presently used to diagnosis M. cozumelae also were also recorded to $M$. bennettii in diverse parts of Brazil, making that validity of M. cozumelae questionable based on this kind of traits. This research also updated the geographic distribution to the M. bennettii in Brazil.
\end{abstract}

KEYWORDS. Morphology, morphometry, Cerrado, Atlantic Forest, distribution.

RESUMO. Distribuição geográfica e variação morfológica em Mimon bennettii (Chiroptera, Phyllostomidae). Foi analisada a morfologia quantitativa e qualitativa de 88 espécimes do subgênero Mimon previamente identificados como Mimon bennettii (Gray, 1838) e M. cozumelae Goldman, 1914 de diversas localidades dentro de sua distribuição. Os dados indicam que os espécimes de Mimon bennetii no Brasil apresentam variação geográfica nos caracteres morfométricos e em mosaico nos qualitativos. Espécimes do bioma Cerrado provenientes dos estados brasileiros do Piauí, Tocantins e Goiás têm antebraço mais longo que os indivíduos dos domínios da Amazônia e Floresta Atlântica. Com base na morfometria aplicando teste t-Student, os espécimes de M. bennettii do Cerrado lembram fenéticamente mais $M$. cozumelae que $M$. bennettii da Floresta Atlântica. Os caracteres morfológicos atualmente empregados para diagnosticar $M$. cozumelae também foram registrados para $M$. bennettii em diversas áreas do Brasil, tornando a validade de $M$. cozumelae questionável nesses tipos de caracteres. O presente artigo também atualiza a distribuição geográfica de $M$. bennettii no Brazil.

PALAVRAS-CHAVES. Morfologia, morfometria, Cerrado, Floresta Atlântica, distribuição.

The subgenus Mimon (Mimon) Gray, 1847 is taxonomically controversial because authors have recognized one species to the subgenus, Mimon bennettii (Gray, 1838) (SANBoRn, 1941; GoOdwin, 1942a; Hershrovitz, 1951; Koopman, 1993; Ortega \& Arita, 1997), or two species, M. bennettii and M. cozumelae Goldman, 1914 (Dalquest, 1957; WinkElMANN, 1962; GARDNER et al., 1970; Jones \& CARTER, 1979; SWANEPOEL \& Genoways, 1979; Genoways et al., 1981; McCarthy, 1987; Simmons \& Voss 1998; Simmons, 2005; Williams \& GENOWAYs, 2007). A third viewpoint recognizes these two taxa at the subspecific level: $M$. $b$. bennettii and $M$. $b$. cozumelae (Goodwin, 1942b; SсHALDACH, 1964). This unsolved scenario is partially due the lack of a comprehensive analysis of variation along the whole range of distribution prior taxonomic decision as a consequence of scarce number of specimens from South America available in collections. The lack of studies using chromosomes and no molecular analysis addressed to solve the taxonomy must be noteworthy. Additionally, the geographical distribution of $M$. bennettii is imprecise.

Mimon bennettii was described based on material collected in South America. Subsequently, Hershкovitz (1951) restricted the type-locality to Ypanema (presently, Ipanema farm, municipality of Bacaetaba), a locality inserted within the Atlantic Forest domain, in the southeastern of state of São Paulo, Southeastern Brazil. This restriction was based on a record of THомаs (1902). Scarcity and widespread housing of specimens in South American collections lead to imprecise limits of $M$. bennettii in that continent (see map in Williams \& GENOWAYs, 2007). Even in Central America, the records of Mimon are scarce, excepting to Belize and Mexico.

Mimon cozumelae occurs from Mexico to southern Central America reaching Costa Rica and Colombia; its type-locality in Isla Cozumel, Mexico. Goldman (1914) based on the larger dimensions of both forearm and skull, and on the paler and brownish dorsal pelage coloration in $M$. cozumelae as diagnostic characters to distinguish the species of $M$. bennettii. Indeed, all these attributes can be noted in holotype and paratypes of M. cozumelae.

Some authors for long have argued pro validity of two species for the subgenus Mimon and they have tentatively defended the position throughout different arguments, but mostly based on morphology in complement with those presented by GoLDMAN (1914) (Dalquest, 1957; Carter et al., 1966; Genoways et al., 1981; Simmons \& Voss, 1998). However, much of these characters, particularly body dimension, are questionable to support the validity for $M$. cozumelae. For example, $M$. cozumelae is known to have larger dimensions of forearm and skull, but many specimens of $M$. bennettii from Brazil 
presented dimension similar or larger than those of $M$. cozumelae (JONES \& CARTER, 1979). Recognizing of both species is upheld by the karyological differences (BAKER et al., 1981), dentition and mesopterygoid fossa morphologies (Simmons \& Voss, 1998; Williams \& Genoways, 2007). Díaz et al. (1986) reported both taxa for Colombia, where $M$. cozumelae occurs at northern and $M$. bennettii is restricted to the Sierra de La Macarena. This would be a good condition (geographical proximity) to compare and define both taxa, but Díaz et al. (1986) unfortunately did not discuss the procedures to identify the specimens neither gave any diagnostic characters used for. Recently, Simmons \& Voss (1998) added many morphological characters beyond those previously presented in literature to contribute with the recognition of both species. Mimon bennettii would be easily distinguished from $M$. cozumelae as summarized: 1) lighter pelage brown-reddish in adults (dark brown in $M$. cozumelae); 2) dark wingtip (white in M. cozumelae); 3) pointed inner upper incisors (spatulated in $M$. cozumelae); 4) narrowed lower incisors at the distal tips (larger lower incisors in M. cozumelae); 5) large talonid on third lower molar (narrow in M. cozumelae); and 6) posterior edge of palate U-shaped rather than V-shaped as in M. cozumelae. In addition, Simmons \& Voss (1998) said that $M$. bennettii present body dimensions slightly smaller than $M$. cozumelae, although some overlap can occur. Authors had few specimens of $M$. bennettii from South American neglecting the variation presented there.

During the last two decades zoological material collected in central-western and northeastern Brazil (states of Piauí, Tocantins, and Goiás - Cerrado biome), southeastern Brazil (states of São Paulo, Espírito Santo and Rio de Janeiro - Atlantic Forest biome), and more recently in the state of Amapá (Amazon biome), resulted in the collection of appreciable number of specimens identified as $M$. bennettii. We detected variation in morphological traits, most geographically related. Thus, this report has as objectives 1) the study of morphological variation in $M$. bennettii along its distribution based on qualitative traits and morphometry, and 2) update the distribution with new records in Brazil.

\section{MATERIAL AND METHODS}

There were analyzed 88 specimens currently found in the following institutions: American Museum of Natural History, New York (AMNH), Universidade Estadual Paulista, UNESP, São José do Rio Preto (DZRP), The Field Museum, Chicago (FMNH), Instituto de Pesquisa Científica e Tecnológica do Estado do Amapá, Macapá (IEPA), Museum of Comparative Zoology, Harvard (MCZ), Museu Nacional, Universidade Federal do Rio de Janeiro, Rio de Janeiro (MNRJ), Museu de Zoologia da Universidade de São Paulo, São Paulo (MZSP), Projeto Morcegos Urbanos, Fundação Zôo-Rio, Rio de Janeiro (PMU), Royal Ontario Museum, Toronto (ROM), and National Museum of Natural History, Smithsonian Institution, Washington D.C. (USNM). One specimen from state of Espírito Santo was kindly given by Dr. A. D. Ditchfield (Universidade Federal do Espírito Santo UFES).
There were analyzed morphology of pelage, wing and skull. For the morphometrical study the following measurements were taken: 1) forearm length (FA), 2) greatest length of skull (GLS), 3) condyle-incisive length (CIL), 4) zigomatic breadth (ZIB), 5) braincase breadth (BB), 6) maxillary canine-incisive length (C-M), and 7) mandibular length (MAL). Definitions of measurements followed the Kalko \& Handley (1994) methodology. Samples of M. bennettii were grouped considering the proximity of the localities, similarities in relief and phytophysionomy of them, and the latitude. The clustered units were 1) southern São Paulo, Brazil (Atlantic forest biome); 2) eastern Bahia, Brazil (Atlantic forest biome); 3) Goiás, Brazil (Cerrado biome); 4) southern Piauí, Brazil (Cerrado biome); 5) Amapá, Brazil (Amazonian forest biome); and 6) Guianas (Amazonian Forest biome). For comparison, Mexican and Central American samples of M. cozumelae were also studied. Grouping procedure was necessary in order to permit the application of statistical tests. The $t$-test (ZAR, 1999) was applied with probability (p) $\leq 0.05$ in order to compare among samples along the previously established north-south track, from Mexico to state of São Paulo, Brazil. For some populations with enough sampling the $t$-test was used for sexual dimorphism. There were applied the Principal Component Analysis (PCA) in order to study the morphometrical variation considering males and females separately. Some specimens studied were not included in PCA analysis because some skulls were damaged. All statistical analyses were performed using Statistica 6.0 (Statsoft, 2001).

Material examined. Mimon bennettii - PANAMA,

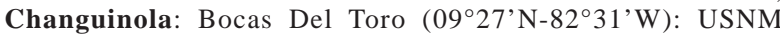
315220-221. COLOMBIA, Bolívar: Socorré (Rio Sinú) (0751’N76¹7'W): FMNH 69425-427. FRENCH GUIANA, Paracou (05²5'N-52 $\left.{ }^{\circ} 55^{\prime} \mathrm{W}\right)$ : AMNH 267109. BRAZIL, Amapá: Floresta Nacional (FLONA) do Amapá (1¹7’N-51³5’W): IEAP 98, 115; Bahia: Salvador: MZSP 16321, 16323-24; Espírito Santo: Reserva Biológica de Duas Bocas, Cariacica (20¹8'S-40³2’W) RF 29. Rio de Janeiro: Paty do Alferes (Fazenda Antas)

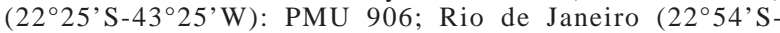

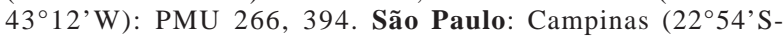
47 $03^{\circ}$ 'W): DZRP 14901,15673; Ipanema Farm (District of

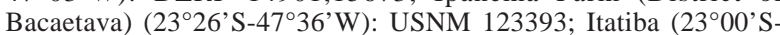
4650’W): DZRP 13549, 13552-556; Juquitiba (235' S-

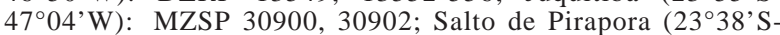
473' W): MZSP 31727-728; Taguaí (23²7’S-49²4’W): DZRP 14374-375. Paraná: Caiobá (coordenates were found): FMNH 136841. Mimon af. bennettii: Piauí: São Raimundo Nonato (includes Parque Nacional Serra das Confusões) (0900'S-42 $41^{\prime}$ W): DZRP 6936-940; MZSP: 106, 129, 133, and DAM 52 (field numbers); Bom Jesus do Piauí (0904'S-44²1'W): DZRP 16941-944; No precise district location: DZRP 16945-946. Goiás: Corumbá de Goiás (1555’S-4848’W): PMU 1306; Mambaí de Goiás (14²9’S4606'W): PMU 2915-16, 2930, 2934, 2936, 2939-40, 3173; Serra da Mesa (1350'S-4 8³0'W): MNRJ 36387, 36872. Minas Gerais:

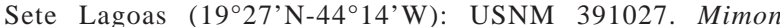
cozumelae: MEXICO, Quintana Roo: Isla Cozumel $\left(20^{\circ} 301^{\prime} \mathrm{N}\right.$ 8640’W): MCZ 22162, USNM 203191 (holotype), 203277. Yucatan: Izamal $\left(20^{\circ} 50^{\prime} \mathrm{N}-89^{\circ} 10^{\prime} \mathrm{W}\right)$ : USNM 172079-80; Santa Elena (20¹9’ N-89³8’W): ROM 96534, 97764; Tekom

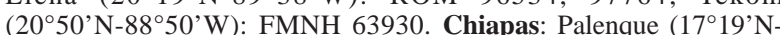
$\left.92^{\circ} 05^{\prime} \mathrm{W}\right)$ : FMNH 150630-31. Oaxaca: Matias Romero $\left(16^{\circ} 20^{\prime} \mathrm{N}\right.$ 95²0'W): AMNH 185862-872, USNM 332689-690. BELIZE, Cayo: Augustine $\left(1^{\circ} 58^{\prime} \mathrm{N}-88^{\circ} 59^{\prime} \mathrm{W}\right)$ : FMNH 58152-153; Barton Creek (17 $\left.13^{\prime} \mathrm{N}-89^{\circ} 57^{\prime} \mathrm{W}\right)$ : FMNH 58155-56, 108764; Churchyard $\left(17^{\circ} 18^{\prime} \mathrm{N}-88^{\circ} 59^{\prime} \mathrm{W}\right)$ : FMNH 58154 . No precise district location $\left(17^{\circ} 11^{\prime} \mathrm{N}-85^{\circ} 00^{\prime} \mathrm{W}\right)$ : FMNH 108765-766. Toledo: Aguacate $\left(16^{\circ} 10^{\prime} \mathrm{N}-89^{\circ} 06^{\prime} \mathrm{W}\right)$ : FMNH 108767; Pueblo Viejo $\left(16^{\circ} 13^{\prime} \mathrm{N}-\right.$ $\left.89^{\circ} 09^{\prime} \mathrm{W}\right)$ : 58151 ; Salamanca $\left(16^{\circ} 16^{\prime} \mathrm{N}-89^{\circ} 01^{\prime} \mathrm{W}\right)$ : AMNH 256823. GUATEMALA, Izabal: San Tomás de Castilla (15²' $\left.\mathrm{N}-88^{\circ} 37^{\prime} \mathrm{W}\right)$ : AMNH 265107. 


\section{RESULTSAND DISCUSSION}

Geographic distribution. Map showing the distribution of Mimon includes localities with specimens studied from our group and records from literature (Fig. 1). In Brazil, $M$. bennettii was restricted to southeastern Brazil (Ortega \& ARITA, 1997; SimMONS, 2005; WiLliams \& GenOways, 2007). However, there is an old record for Corumbá, southwestern Brazil (MirandA-RiBEIRo, 1914), and more recently, individuals of $M$. bennettii were reported in Gruta Morro, Distrito Federal (BREDT et al., 1999), state of Paraná (Mirestski, 2003), state of Santa Catarina (Cherem et al., 2004), Mambaí, state of Goiás, (EsBÉRARD et al., 2005), and some localities in the state of Amapá (MARTins et al., 2006). Record to Corumbá needs further verification about the identity of species, and information about Itacarambi, located in the north of Minas Gerais as mentioned for EsBÉRARD et al. (2005, tab. 4) is misunderstood. Our new records from states of Bahia, Goiás, and Piauí extend the distribution of the species to the northeastern and central-western regions of Brazil, and indicate that $M$. bennettii also occurs in drier habitats such as the Cerrado and the transitional vegetation between the Cerrado and the Caatinga, areas not mapped by WiLLIAMS \& GENOWYAS (2007).

REID (1997) considered only one species for the subgenus Mimon and mentioned that $M$. bennettii habits the lowland in Central America and Mexico. In contrast, specimens of $M$. bennettii from state of Piauí and several portions of the Atlantic Forest were captured in areas up 1,000 m high. Specimens from Bahia deserve special attention, because that state encompasses several biomes (e. g., Caatinga, Cerrado, and Atlantic Forest). The material from Bahia was collected by B. Bicego, who indicated the locality as “Baia”, more precisely Salvador, in the Atlantic Forest, as recently proposed (GREGORIN et al., 2006). Records of M. bennettii in other parts of South America include the southeastern Colombia (DíAz et al., 1986; Montenegro \& Romero-Ruiz, 1999; Alberico et al., 2000), eastern Venezuela (Molina et al., 1995), Guiana (Smith \& Kerry, 1996; Lim \& Engstrom, 2001), French Guiana (Brosset \& Charles-Dominique, 1990; Simmons
\& Voss, 1998), and northern Suriname (Husson, 1962; Genoways et al., 1981) (Fig. 1). Mimon bennettii was reported to northern Venezuela (ALLEN, 1911; EISENBERG, 1989) and Río Mavaca, Amazonas, published in Molina et al. (1995). Thus, M. bennettii presently is restricted to South America, and Mimon cozumelae is known from southern Mexico to Colombia (SImMOns, 2005; WILliams \& GENOWAYS, 2007).

In that context, we emphasize that two specimens from Bocas del Toro, Panama (USNM 315220 and 315221), presented reddish-brown coloration in pelage as described for $M$. bennettii from southeastern Brazil, but in PCA analysis (see below) the specimen USNM 315221 is plotted close to the specimens of $M$. cozumelae. Curiously, the specimen from Panama was identified by Dr. Charles Handley as $M$. bennettii throughout comparison with the holotype of that species housed at the British Museum, as noted for himself on the tag of USNM specimen. On the other hand, one adult male specimen of M. cozumelae from Colombia was identified based on forearm as long as 56.5 mm (MARINKELLE \& CADENA, 1972). This dimension of forearm overlaps with variation of $M$. bennettii and not M. cozumelae (Jones \& CARTER, 1979, and Tab. I). These data show a confused scenario in identifying both taxa and their geographical limits when both species are assumed be valid and altough morphometrical data were used to diagnostic them.

Qualitative morphological analysis. Pelage and wingtip coloration - Adult specimens of $M$. bennettii from states of Minas Gerais (USNM 391027) and São Paulo (DZRP 13549, 13552-57, 14374-75, 15673; MZSP 30900, 30902, 31727-28) have pale brown pelage dorsally, with the tip of hairs rusty brown and about 3/4 of the hair dirty white or slightly grayish at the base. The hairs on the lumbar region are monochromatic pale brown. This coloration is similar to that described by Simmons \& Voss (1998) to identify M. cozumelae. Juvenile specimen from Ipanema farm, state of São Paulo (USNM 123393), it has dark dorsal pelage coloration with grayish rues. Variation in pelage coloration, whether grayish or brownish, may be related to age or to individual variation, rather than the geographical or taxonomic differences. However the

Table I. Results of the descriptive statistics for males of Mimon bennettii (Gray, 1838) and M. cozumelae Goldman, 1914 (with asterisks) of seven sample series studied including mean and standard deviation (upper line), and minimum, maximum, and number of specimens (n) (bottom line). All measurements are given in millimeters (mm).

\begin{tabular}{|c|c|c|c|c|c|c|c|}
\hline Variables & Mexico * & Guianas & Amapá & Piauí & Goiás & Bahia & São Paulo \\
\hline FA & $\begin{array}{c}56.5 \pm 1.8 \\
(53.0-60.0) 12\end{array}$ & $\begin{array}{c}53.6 \pm 0.6 \\
(53.1-54.0) 2\end{array}$ & 55.8 & $\begin{array}{c}58.4 \pm 0.8 \\
(57.2-59.3) 6\end{array}$ & $\begin{array}{c}57.5 \pm 1.4 \\
(54.7-59.2) 8\end{array}$ & 56.2 & $\begin{array}{c}53.9 \pm 1.5 \\
(51.8-57.6) 10\end{array}$ \\
\hline GLS & $\begin{array}{c}25.6 \pm 0.4 \\
(24.9-26.5) 10\end{array}$ & $\begin{array}{c}25.5 \pm 0.2 \\
(25.4-25.6) 2\end{array}$ & 25.9 & $\begin{array}{c}24.8 \pm 0.4 \\
(24.5-25.4) 4\end{array}$ & $\begin{array}{c}25.7 \pm 0.3 \\
(25.4-26.0) 4\end{array}$ & & $\begin{array}{c}24.4 \pm 0.5 \\
(24.0-25.3) 5\end{array}$ \\
\hline CIL & $\begin{array}{c}23.2 \pm 0.3 \\
(22.7-23.7) 10\end{array}$ & $\begin{array}{c}22.6 \pm 0.9 \\
(22.0-23.9) 2\end{array}$ & 23.1 & $\begin{array}{c}22.9 \pm 0.5 \\
(22.4-23.6) 4\end{array}$ & $\begin{array}{c}23.0 \pm 0.5 \\
(22.5-23.6)\end{array}$ & & $\begin{array}{c}22.3 \pm 0.2 \\
(22.1-22.6) 5\end{array}$ \\
\hline ZIB & $\begin{array}{c}13.8 \pm 0.3 \\
(13.4-14.3) 10\end{array}$ & $\begin{array}{c}13.9 \pm 0.0 \\
(13.9-13.9) 2\end{array}$ & 13.8 & $\begin{array}{c}13.0 \pm 0.3 \\
(12.6-13.4) 4\end{array}$ & $\begin{array}{c}13.6 \pm 0.4 \\
(13.3-14.2) 4\end{array}$ & 13.3 & $\begin{array}{c}13.3 \pm 0.2 \\
(13.0-13.5) 4\end{array}$ \\
\hline BB & $\begin{array}{c}10.0 \pm 0.3 \\
(9.5-10.8) 10\end{array}$ & 10.1 & 9.7 & $\begin{array}{c}9.6 \pm 0.1 \\
(9.5-9.7) 4\end{array}$ & $\begin{array}{c}10.0 \pm 0.2 \\
(9.7-10.2) 4\end{array}$ & & $\begin{array}{c}9.6 \pm 0.2 \\
(9.3-9.8) 5\end{array}$ \\
\hline C-M & $\begin{array}{c}9.4 \pm 0.1 \\
(9.1-9.6) 11\end{array}$ & & 9.4 & $\begin{array}{c}9.4 \pm 0.2 \\
(9.3-9.7) 4\end{array}$ & $\begin{array}{c}8.9 \pm 0.6 \\
(8.1-9.4) 4\end{array}$ & 9.1 & $\begin{array}{c}9.0 \pm 0.2 \\
(8.8-9.2) 6\end{array}$ \\
\hline MAL & $\begin{array}{c}17.9 \pm 0.2 \\
(17.5-18.1) 11\end{array}$ & & 17.3 & $\begin{array}{c}17.3 \pm 0.2 \\
(17.2-17.6) 4\end{array}$ & $\begin{array}{c}17.1 \pm 0.1 \\
(17.0-17.3) 4\end{array}$ & 17.1 & $\begin{array}{c}16.4 \pm 0.3 \\
(16.1-16.9) 6\end{array}$ \\
\hline
\end{tabular}




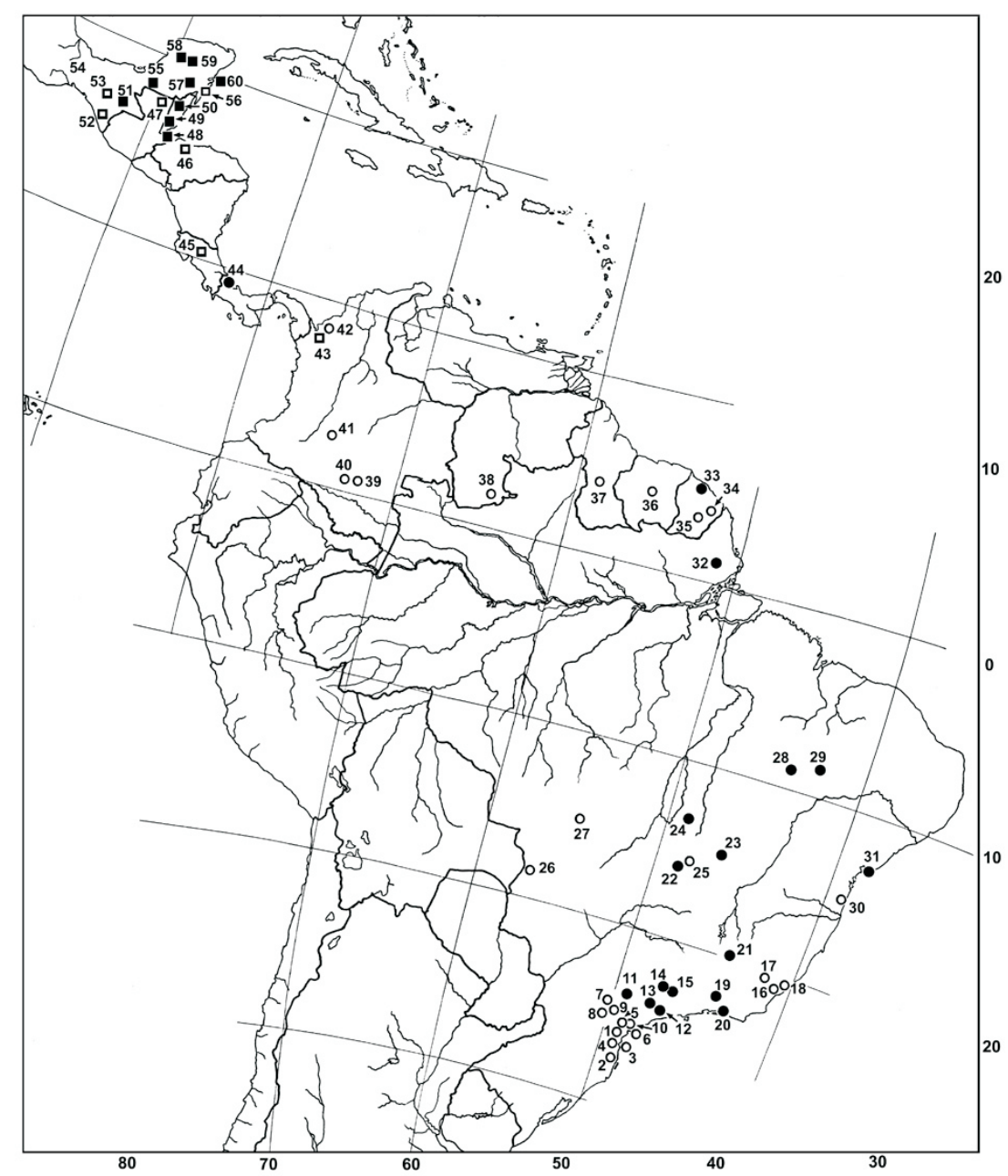

Fig. 1. Map showing records of Mimon bennettii (Gray, 1838) and M. cozumelae Goldman, 1914 as previously identified in the tags of specimens or literature. Full symbols indicate material analyzed for us and open symbols indicate records compiled from literature as followed in parenthesis after some localities. Circules denote M. bennettii and squares M. cozumelae. Brazil: 1, Colônia Hansa (presently Corupá) (VIEIRA, 1942); 2, Santo Amaro da Imperatriz; 3, Florianópolis (includes Ilha do Arvoredo); 4, Blumenau (2-4 from Cherem et al., 2004); 5, Curitiba; 6, Ilha do Mel (5-6 from Miretski, 2003); 7, Fazenda Monte Alegre, Telâmaco Borba; 8, Floresta Nacional do Irati, Fernandes Pinheiro (7-8 from Reis et al., 1999); 9, Cigarreira; 10 - Mãe Catira, Morretes (9- 10 from MiRetski, 2003); 11, Taguaí; 12, Juquitiba; 13, Ipanema (type-locality of M. bennettii) (includes Salto do Pirapora); 14, Campinas; 15, Itatiba; 16, Iconha (Tahara, A., com. pes.); 17, Gruta do Limoeiro, Castelo (Tahara, A., com. pes.); 18, Duas Bocas, Cariacica (M. Scabello, com. pes); 19, Paty de Alfores (Fazenda Antas); 20, Rio de Janeiro; 21, Sete Lagoas; 22, Corumbá de Goiás; 23, Mambaí de Goiás; 24, Serra da Mesa; 25, Brasília (Bredt et al., 1999), 26, Corumbá (Miranda-Ribeiro, 1914 - this record must be verified); 27, Chapada dos Guimarães (Tahara, A., com. pes.); 28, Bom Jesus do Piauí; 29, São Raimundo Nonato; 30, Ilhéus (FARIAs et al., 2006); 31, Salvador; 32, FLONA Amapá. French Guiana: 33, Paracou.; 34, Arataye (Lim \& Engstrom, 2001); 35, Saül (Brosset \& Charles-Dominique, 1990). Suriname: 36 - Saramacca (Genoways et al., 1981). Guiana: 37, Iwokrama (Lim \& Engstrom, 2001). Venezuela: 38, Río Mavaca (Molina et al., 1995). Colombia: 39, El Bombonal, Río Mesay; 40, Puerto Abeja, Caqueta (39-40 from Montenegro \& Romero-Ruiz, 1999); 41, Sierra de La Macarena (Díaz et al. 1986); 42, Rio Sinú, Socorré, Bolívar; 43, Chigorodó, Antioquia (Marinkele \& CadenNa, 1972). Panama: 44, Bocas Del Toro. Costa Rica: 45, Finca La Selva, Puerto Viejo, Heredia (La VAL, 1977). Honduras: 46, Lancetilla (VALDEZ \& La Val, 1971). Guatemala: 47, Tikal, Petén (McCarthy, 1982); 48, San Tomás de Castilla, Izabal. Belize: 49, Pueblo Viejo, Toledo (includes Aguacate and Salamanca); 50, Barton Creek (Augustine and includes Churchyard). Mexico: 51, Palenque, Chiapas; 52, Mal Paso, Chiapas (Carter et al., 1966); 53, Teaba, Tabaco (Wilkeman, 1962); 54, Matias Romero, Oaxaca; 55, Pisté, Tixpehual (includes Constitucion, Campeche - Jones et al., 1973); 56, Tekom, Yucatan; 57, Santa Elena, Yucatan; 58, Calcehtok, Yucatan (Jones et al., 1973); 59, Izamal; 60, Isla Cozumel (type-locality of M. cozumelae).

characterization of more specimens is necessary to define the degree of variation in dorsal pelage of $M$. bennettii.

All specimens from Bahia and São Paulo have white wingtips (MZSP 16321, 16323-24; MZSP 30900, 30902) whereas specimens from other places studied in this research showed black wingtips. Two specimens collected in same site in the state of Amapá (IEPA 98 and 115), both identified as $M$. bennettii based on forearm length, presented variation, one with white wingtips while the other one showed dark wingtips.
Skull. There were studied variation in palate morphology in twenty-two skulls of $M$. bennettii from central, northeastern and eastern Brazil (states of São Paulo, Goiás, Bahia, Espírito Santo, and Piauí) with special attention to the shape of posterior border of palate, whether U or V-shaped. Simmons \& Voss (1998) and Williams \& Genoways (2007) used this character to distinguish between $M$. bennettii (U-shaped) and $M$. cozumelae (V-shaped). Ten specimens of typical $M$. bennettii had a U-shaped palate (e. g., DZRP 13552, 16942, 
16946; MNRJ 36387, 36872) and twelve individuals presented V-shaped ones (e.g., DZRP 16943, 13553-54, 14901; PMU 1306, 2934). We concluded that shape of posterior edge of palate may be attributed to individual variation rather than to taxonomic or geographically ones, since variation was widespread in all Brazilian samples. We also examined 62 skulls to study variation of inner upper incisors morphology, as it was indicated as another useful character to distinguish both species by SimMONS \& Voss (1998). Most specimens (fifty) from diverse localities in Central and South America had spatulate inner upper incisors, while twelve had inner upper incisors tapered shape as defined by Simmons \& Voss (1998). Specimens from eastern Brazil presented both conditions of upper incisors revealing the polymorphism in this character. Also, differences in talonid on molar as used for Simmons \& Voss (1998) were not substantial to distinguish $M$. cozumelae and $M$. bennettii because the dimensions of that region are similar in both taxa.

Morphometrical characters. We applied $t$-test to three samples, including two of $M$. bennettii (states of Piauí and São Paulo, Brazil) and one of M. cozumelae (Mexico), in order to test any level for sexual differences, noting that samples are scarce to a definitive position of this concerning. Only specimens from São Paulo had significant sexual differences with females larger than the males: forearm length ( $p=0.015)$, greatest length of skull $(p=0.015)$, condyle-incisive length $(p=0.011)$, length of maxillary toothrow $(\mathrm{p}=0.028)$, and length of mandible $(p=0.001)$. Therefore, analyses were conducted considering males and females separately.

Data of the descriptive statistical analysis of selected samples in a north-south track are plotted on the tables I and II. Results showed that specimens from Piauí (M. aff. bennettii) had the largest forearm measurements, while specimens from Mexico (typical $M$. cozumelae) have largest skulls. The $t$-tests for four samples are summarized in the tables III and IV. Males and females from Piauí differ in four and two variables, respectively, from specimens from São Paulo. Furthermore, the samples of Goiás differs in body dimensions when compared to Piauí and São Paulo samples, being slightly smaller than the earlier and larger than the second one.
Specimens from central-western (Goiás) and northeastern Brazil (Piauí) were biometrically different from the Mexican samples in both sex. Data indicate that central-western and northeastern Brazilian specimens, mainly from the state of Piauí, comprise a peculiar morphological sizerelated population.

We included specimens previously identified as M. bennettii and M. cozumelae in our PCA analysis. In males, factor 1 was responsible for $65.4 \%$ of variation $(\mathrm{CIL}=0.216 ; \mathrm{GLS}=0.209 ; \mathrm{MAL}=0.203)$ and factor 2 comprises $15.8 \%(\mathrm{FA}=0.668$; ZIB $=0.307)($ Fig. 2$)$, with two first components responsible for $81.2 \%$ of total variation. Distribution of the plots represented by specimens from states of Goiás and Piauí are clustered separately of another plots (representing formally $M$. bennettii and $M$. cozumelae) by the factor 2 as showed at the fig. 2. The length of forearm was the main responsible for the subdivision into two distinct groups in the plot of first and second components. First factor separates $M$. cozumelae (squares) of $M$. bennettii from Amazonian and Atlantic forests (triangles). Curiously, one specimen on the left of the graph (USNM 315221 - from Panama) previously identified as $M$. bennettii by its pelage is clustered with $M$. cozumelae (see discussion above). The same is applied to a specimen from Juquitiba (MZSP 30900), a place near of the type-locality of $M$. bennettii, because it had a long forearm $(57.05 \mathrm{~mm})$, and was placed together with the samples from Piauí. Discriminant analysis indicates that specimens identified as $M$. cozumelae are distinct of the South American specimens (from samples of Amazonian and Atlantic forest p-level $=0.00018$; from samples collected in the states of Goiás and Piauí p-level =0.00001). Samples from states of Goiás and Piauí are slightly distinct from samples obtained in Atlantic and Amazonian forest (p-level = (0.051).

In the PCA for females (Fig. 3), factor 1 was responsible for $59.3 \%$ of the variation $(\mathrm{CIL}=0.22$; $\mathrm{ZIB}=$ 0.21 ; $\mathrm{C}-\mathrm{M}=0.2$; MAL $=0.19$ ) while factor 2 was responsible for $17.7 \%$ of variation $(\mathrm{FA}=0.79)$. Both factors were responsible for $76.9 \%$ of total variation. Results of the PCA for females were inconsistent compared for males, because discriminant analysis

Table II. Results of the descriptive statistics for females of Mimon bennettii (Gray, 1838) and M. cozumelae Goldman, 1914 (with asterisks) of six sample series studied including mean and standard deviation (upper line), and minimum, maximum, and number of specimens (n) (bottom line). All measurements are given in millimeters ( $\mathrm{mm}$ ).

\begin{tabular}{|c|c|c|c|c|c|c|}
\hline Variables & Mexico * & Amapá & Piauí & Goiás & Bahia & São Paulo \\
\hline FA & $\begin{array}{c}56.2 \pm 0.9 \\
(55.1-57.2) 7\end{array}$ & 53.25 & $\begin{array}{c}59.3 \pm 1.2 \\
(57.7-60.4) 4\end{array}$ & $\begin{array}{c}57.5 \pm 0.6 \\
(56.8-57.9) 3\end{array}$ & $\begin{array}{c}54.8 \pm 0.3 \\
(55.0-54.6) 2\end{array}$ & $\begin{array}{c}55.7 \pm 1.0 \\
(54.5-57.8) 8\end{array}$ \\
\hline GLS & $\begin{array}{c}25.5 \pm 0.3 \\
(25.2-25.8) 5\end{array}$ & 25.8 & $\begin{array}{c}24.8 \pm 0.3 \\
(24.4-25.1) 3\end{array}$ & $\begin{array}{c}25.7 \pm 0.4 \\
(25.2-26.1) 3\end{array}$ & & $\begin{array}{c}25.2 \pm 0.5 \\
(24.4-25.9) 7\end{array}$ \\
\hline CIL & $\begin{array}{c}23.3 \pm 0.3 \\
(23.0-23.6) 5\end{array}$ & 32.1 & $\begin{array}{c}23.1 \pm 0.3 \\
(22.9-23.5) 3\end{array}$ & $\begin{array}{c}23.2 \pm 0.4 \\
(22.8-23.6) 3\end{array}$ & 22.2 & $\begin{array}{c}22.8 \pm 0.4 \\
(22.3-23.2) 7\end{array}$ \\
\hline ZIB & $\begin{array}{c}13.8 \pm 0.1 \\
(13.7-14.1) 5\end{array}$ & 13.9 & $\begin{array}{c}13.2 \pm 0.1 \\
(13.1-13.3) 3\end{array}$ & $\begin{array}{c}14.0 \pm 0.2 \\
(13.9-14.3) 3\end{array}$ & 13.3 & $\begin{array}{c}13.5 \pm 0.2 \\
(13.1-13.8) 7\end{array}$ \\
\hline BB & $\begin{array}{l}10.0 \pm 0.2 \\
(9.7-10.2) 5\end{array}$ & 9.8 & $\begin{array}{c}9.6 \pm 0.1 \\
(9.5-9.7) 3\end{array}$ & $\begin{array}{c}9.5 \\
(9.5) 1\end{array}$ & & $\begin{array}{c}9.6 \pm 0.2 \\
(9.4-9.9) 7\end{array}$ \\
\hline C-M & $\begin{array}{c}9.4 \pm 0.2 \\
(9.2-9.7) 5\end{array}$ & 9.6 & $\begin{array}{c}9.3 \pm 0.2 \\
(9.1-9.4) 3\end{array}$ & $\begin{array}{c}9.5 \pm 0.4 \\
(9.1-9.8) 3\end{array}$ & 9.0 & $\begin{array}{c}9.2 \pm 0.1 \\
(9.0-9.3) 7\end{array}$ \\
\hline MAL & $\begin{array}{c}17.9 \pm 0.1 \\
(17.7-18.0) 5\end{array}$ & 17.4 & $\begin{array}{c}17.7 \pm 0.2 \\
(17.4-17.8) 3\end{array}$ & $\begin{array}{c}17.7 \pm 0.3 \\
(17.5-17.9) 2\end{array}$ & 16.9 & $\begin{array}{c}17.0 \pm 0.2 \\
(16.7-17.3) 7\end{array}$ \\
\hline
\end{tabular}


Table III. Results of the $t$-test comparing four samples (only males) of Mimon bennettii (Gray, 1838) and M. cozumelae Goldman, 1914 (with asterisks) from Central and South America, in a northsouth track. Note that the specimens from Piauí, São Paulo, and Mexico are overally distinct each other in four or five variables.

\begin{tabular}{|c|c|c|c|c|}
\hline & Mexico * & Piauí & Goiás & São Paulo \\
\hline \multirow[t]{4}{*}{ Piauí } & $F A=0.000$ & & & \\
\hline & $\mathrm{BB}=0.001$ & & & \\
\hline & $\mathrm{ZIB}=0.017$ & & & \\
\hline & $\mathrm{MAL}=0.000$ & & & \\
\hline \multirow[t]{2}{*}{ Goiás } & $\mathrm{C}-\mathrm{M}=0.027$ & $\mathrm{GLS}=0.011$ & & \\
\hline & $\mathrm{MAL}=0.000$ & $\mathrm{ZIB}=0.010$ & & \\
\hline \multirow[t]{5}{*}{ São Paulo } & $\mathrm{GLS}=0.032$ & $\mathrm{FA}=0.000$ & $\mathrm{FA}=0.001$ & \\
\hline & $\mathrm{BB}=0.005$ & $\mathrm{CIL}=0.028$ & $\mathrm{GLS}=0.029$ & \\
\hline & $\mathrm{ZIB}=0.014$ & $\mathrm{C}-\mathrm{M}=0.003$ & $\mathrm{CIL}=0.032$ & \\
\hline & $\mathrm{C}-\mathrm{M}=0.000$ & MAL $=0.002$ & $\mathrm{ZIB}=0.019$ & \\
\hline & MAL $=0.000$ & & MAL $=0.016$ & \\
\hline
\end{tabular}

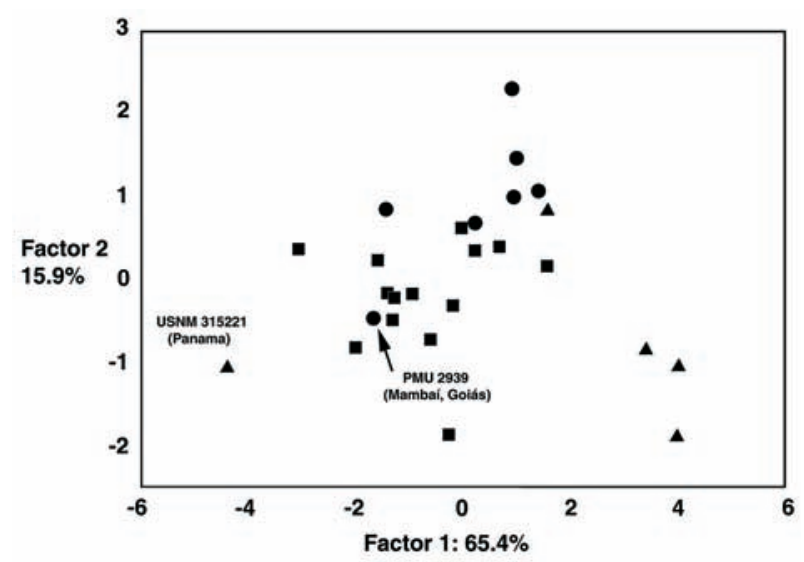

Fig. 2. Scatterplot of first and second factors of the PCA analysis for males of Mimon bennettii (Gray, 1838) (South America and Panama) and M. cozumelae Goldman, 1914 (from Mexico and Belize). Triangle, specimens from state of São Paulo, southestern Brazil, and Bocas del Toro, Panama; square, specimens from Mexico and Belize; circle, specimens from states of Piauí and Goiás, Brazil. See Fig. 1 for the geographical account.

indicated no significance among the samples. P-level comparing samples of $M$. cozumelae with samples from Brazilian states of Goiás and Piauí, and samples from Amazonian and Atlantic forests were, respectively, 0.77 and 0.5. Comparison of last two samples (states of Goiás and Piauí x Amazonian and Atlantic forests) had p-level of 0.14. However, like in males, specimens from Panama and Colombia were plotted together with specimens from Mexico and Belize (M. cozumelae).

Distinction among Brazilian Cerrado specimens and the validation of M. cozumelae. We concluded that Mimon cozumelae is not morphologically easy to separate from $M$. bennettii based solely on qualitative characters presently used (e. g., McСаRTHy, 1987; Simmons \& Voss, 1998; Williams \& Genoways, 2007), although PCA analysis showed that males from Mexico, Belize, and Panama are morphometricaly distinct from South American specimens. This morphometrical distinctiveness in addition with the karyological data (BAKER et al., 1981) may to support the validation of $M$. cozumelae. For the description of M. cozumelae,
Table IV. Results of $t$-test comparing four samples (only males) of Mimon bennettii (Gray, 1838) and M. cozumelae Goldman, 1914 (with asterisks) from Central and South America, in a north-south track. Note that the specimens from Mexico differ of those from northeastern (Piauí) and southeastern (São Paulo) Brazil.

\begin{tabular}{|c|c|c|c|c|}
\hline & Mexico * & Piauí & Goiás & São Paulo \\
\hline \multirow[t]{4}{*}{ Piauí } & $\mathrm{FA}=0.000$ & & & \\
\hline & $\mathrm{GLS}=0.009$ & & & \\
\hline & $\mathrm{CIL}=0.000$ & & & \\
\hline & $\mathrm{ZIB}=0.030$ & & & \\
\hline \multirow[t]{2}{*}{ Goiás } & $\mathrm{FAL}=0.043$ & GLS $=0.045$ & & \\
\hline & & $\mathrm{CIL}=0.005$ & & \\
\hline \multirow[t]{5}{*}{ São Paulo } & $\mathrm{GLS}=0.028$ & & & \\
\hline & $\mathrm{CIL}=0.015$ & $\mathrm{FAL}=0.000$ & $\mathrm{FA}=0.034$ & \\
\hline & $\mathrm{ZIB}=0.013$ & MAL $=0.002$ & $\mathrm{CIL}=0.012$ & \\
\hline & $\mathrm{C}-\mathrm{M}=0.007$ & & MAL $=0.007$ & \\
\hline & MAL $=0.000$ & & & \\
\hline
\end{tabular}

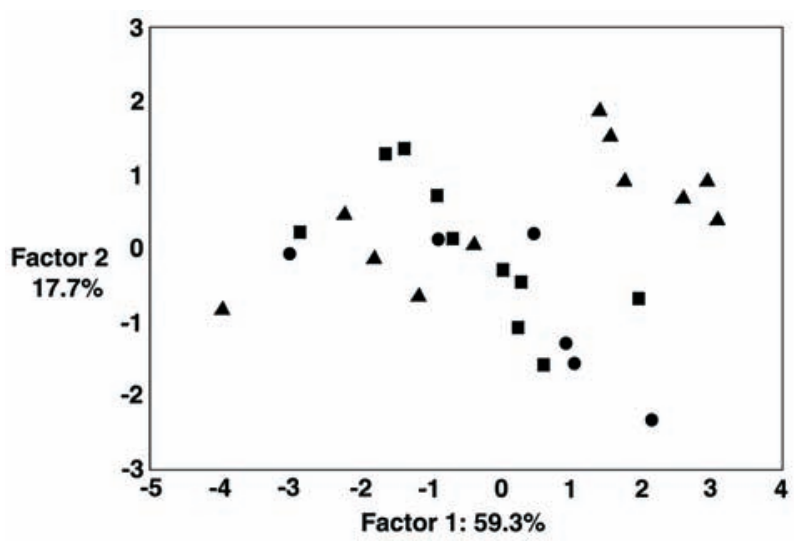

Fig. 3. Scatterplot of first and second factors of the PCA analysis for females of Mimon bennettii (Gray, 1838) (South America and Panama) and M. cozumelae Goldman, 1914 (from Mexico and Belize). Triangle: specimens from states of São Paulo and Minas Gerais, SE Brazil, Bocas del Toro, Panama, and Socorré, Colombia; square: specimens from Mexico and Belize; circle: specimens from states of Piauí and Goiás, Brazil. See map on Fig. 1 for the geographical account.

GoLDMAN (1914) compared adult specimens from Cozumel Island, Mexico, with only one subadult specimen from Ipanema, São Paulo, Southeastern Brazil (representing $M$. bennettii). In that time, validity of the new species seemed obvious, because specimens from Mexico were larger in body and skull dimensions, and the pelage was further red and light than that specimen from São Paulo. Also, both taxa presented, in that time, a large distributional gap of some thousands of kilometers through northern South America and whole Central America. However, as previously reported, the smaller size and darker pelage of the specimen of $M$. bennettii from Brazil that Goldman (1914) considered for comparison was based on a subadult. Adult specimens of $M$. bennettii from southern, central and northeastern Brazil studied here presented pelage coloration similar to those specimens from Mexico and Belize, in which GoOdMAN (1914) used for his description of M. cozumelae. Also, new records have reduced the distributional gap between northernmost (Mexico) and southernmost (southern and southeastern Brazil) records for Mimon. 
The characters presented by Simmons \& Voss (1998) to separate $M$. cozumelae and $M$. bennettii also showed variation in many specimens from Mexico and mainly in Brazil, including those from the southeastern were the type-locality of $M$. bennettii is situated.

Specimens from central-western and northeastern Brazil presented the longest forearm length (Tabs. I and II) in South America and there is no sexual differentiation based on scarce available samples. In contrast, specimens from São Paulo, formerly representing the typical $M$. bennettii, presented a significant sexual differentiation (females are bigger than males in most measurements) and they also have the shortest length of forearm. Specimens from Guianas and Brazilian state of Amapá presented dimensions of forearm like those recorded from São Paulo, but we were unable to test the sexual variation of them. Descriptive statistics revealed (Tabs. I-IV) that the greatest variation in South American samples is restricted to the forearm length. Although small samples were studied, this variation might be habitat-related as a hypothesis to be tested in the future. Specimens from Guianas, and the Brazilian states like Amapá, Bahia, Espírito Santo, and São Paulo inhabit evergreen tropical forest and they showed forearms around $51.0-57.0 \mathrm{~mm}$, with the average of $54.0 \mathrm{~mm}$, whereas individuals from states of Piauí and Goiás were collected in the Cerrado biome, and trend to present longer forearm about 54.7 $59.0 \mathrm{~mm}$. Thus, our data suggest that there may have a correlation between the length of the forearm and the use of habitat, where bats flying in more open vegetation, as Cerrado, in comparison with Atlantic Forest, trend to have wider wingspans.

The Cerrado and Caatinga biomes of Brazil have long been considered areas with low mammalian endemism, particularly when compared to Atlantic and Amazonian forests (Marinho-Filho et al., 1994). However, in last five years one new bat genus and at least three species have been described for these biomes (GREGORIn \& DitchFIELD, 2005; GREGORIN et al., 2006; V. TADDEI, pers. com.), indicating that, at least from the bat fauna perspective, this diversity is underestimated. The large dimensions of specimens of $M$. bennettii from Piauí and Goiás deserve special attention, and studies of additional samples and data (e.g., molecular analysis) are recommended to define the taxonomy of subgenus Mimon in South America.

Acknowledgments. We are grateful to Bruce Patterson (FMNH), Nancy Simmons (AMNH), Mario de Vivo (MZSP), Judith Chupasko (MCZ), João A. de Oliveira (MNRJ), Carlos Esbérard (PMU), Don Wilson (USNM), Judith Eger (ROM), and Arthur Tahara for kindly allowing us to study the specimens under their care. We also thank Enrico Bernard, who kindly shared his unpublished data from Amapá, and to Erica M. Sampaio, Valéria Tavares, and two anonymous referees for criticism and comments on the manuscript. This study was supported by FAPESP, Process 01/07067-6, CNPq process 484283/2006-5, Ernest Mayr Grants (Museum of Comparative Zoology), and The Field Museum Grants.

\section{REFERENCES}

Alberico, M.; Cadena, A.; Hernández-Camacho, J. \& Muñoz-Saba, Y. 2000. Mamíferos (Synapsida: Theria) de Colombiana. Biota Colombiana 1(1):43-75.
Allen, J. A. Mammals from Venezuela collected by Mr. M. A. Carriker, Jr., 1909-1911. Bulletin of the American Museum of Natural History 30(10):239-273.

Baker, R. J.; Genoways, H. H. \& Seyfarth, P. A. 1981. Results of the Alcoa Foundation-Suriname Expeditions. VI. Additional chromosomal data for bats (Mammalia: Chiroptera) from Suriname. Annals of Carnegie Museum of Natural History 50:333-344.

Bredt, A.; Uieda, W. \& Magalhães, E. D. 1999. Morcegos cavernícolas da região do Distrito Federal, centro-oeste do Brasil (Mammalia, Chiroptera). Revista Brasileira de Zoologia 16(3):731-770.

Brosset, A. \& Charles-Dominique, P. 1990. The bats from French Guiana: a taxonomic, faunistic and ecological approach. Mammalia 54(4):509-560.

Carter, D. C.; Pine, R. H. \& Davis, W. B. 1966. Notes on Middle American bats. The Southwestern Naturalist 11(4):488-499.

Cherem, J. J.; Simões-Lopes, P. C.; Althoff, S. \& Graipel, M. E. 2004. Lista dos mamíferos do Estado de Santa Catarina, Sul do Brasil. Mastozoología Neotropical 11(2):151-184.

Dalquest, W. W. 1957. American bats of the genus Mimon. Proceedings of the Biological Society of Washington 70:45-48.

Díaz, A. C.; Camacho, J. H. \& Cadena, G, A. 1986. Lista Actualizada de los mamiferos de Colombia. Anotaciones sobre su distribucion. Caldasia 15:471-501.

Eisenberg, J. F. 1989. Mammals of the Neotropics. The northern Neotropics. Chicago, The Chicago University. $x$ $+449 p$.

Esbérard, C. E. L.; Motta, C. A. \& Perigo, C. 2005. Morcegos cavernícolas da Área de Proteção Ambiental (APA) Nascentes do Rio Vermelho, Goiás. Revista Brasileira de Zoociências 7(2):311-325.

Faria, D. M.; Santos, B. S. \& Sampaio, E. M. 2006. Bats from the Atlantic rainforest of southern Bahia, Brazil. Biota Neotropica 6(2):1-13.

Gardner, A. L.; La Val, R. K. \& Wilson, D. E. 1970. The distributional status of some Costa Rican bats. Journal of Mammalogy 51(4):712-729.

Genoways, H. H.; Williams, S. L. \& Groen, J. A. 1981. Results of the Alcoa Foundation-Suriname Expeditions. V. Noteworthy records of Surinamese mammals. Annals of the Carnegie Museum 50(11):319-332.

Goldman, E. A. 1914. A new bat of the genus Mimon from Mexico. Proceedings of the Biological Society of Washington 27:75-76.

Goodwin, G. G. 1942a. Mammals from the state of Oaxaca, Mexico, in the American Museum of Natural History. Bulletin of the American Museum of Natural History 141(1):1-269.

1942b. Mammals of Honduras. Bulletin of the American Museum of Natural History 79:107-195.

Gregorin, R. \& Ditchfield, A. D. 2005. New genus and species of nectar-feeding bat in the tribe Lonchophyllini (Phyllostomidae: Glossophaginae) from northeastern Brazil. Journal of Mammalogy 86(2):403-414.

Gregorin, G.; Gonçalves, E.; Lim, B. K. \& Engstrom, M. 2006. New species of disk-winged bat Thyroptera and range extention for T. discifera. Journal of Mammalogy 87(2):238-246.

Hershrovitz, P. 1951. Mammals from British Honduras, Mexico, Jamaica and Haiti. Fieldiana Zoology 31(47):547-569.

Husson, A. M. 1962. The bats of Suriname. Leiden, E. J. Brill. 282p.+ 30pls.

Jones, J. K., JR. \& Carter, D. C. 1979. Annoted checklist with keys to subfamilies and genera. In: BAKER, R. J.; JONES, J. K., JR. \& CARTER, D. C. eds. Biology of bats of the New World family Phyllostomatidae, part I. Special Publications Texas Tech University 10. p.7-38.

Jones, K. K., JR.; Smith, J. D. \& Genoways, H. H. 1973. Annotated checklist of mammals of the Yucatan Peninsula, Mexico. I. Chiroptera. Occasional Papers the Museum Texas Tech University 13:1-31.

Koopman, K. F. 1993. Order Chiroptera. In: Wilson, D. E. \& ReEder, D. M. eds. Mammals species of the World, a taxonomic and geographic reference. 2nd Edition. Washington D.C., Smithsonian Institution. p.137-241. 
La VAL, R. K. 1977. Notes on some Costa Rican bats. Brenesia 10/11:77-83.

Lim, B. K. \& Engstrom, M. D. 2001. Species diversity of bats (Mammalia: Chiroptera) in Iwokrama Forest, Guyana, and the Guianan subregion: implications for conservation. Biodiversity and Conservation 10:613-657.

Marinho-Filho, J.; Reis, M. L.; Oliveira, P. S.; Vieira, E. M. \& Paes, M. N. 1994. Diversity standarts and small mammal number: conservation of the Cerrado biodiversity. Anais da Academia brasileira de Ciências 66 (Supl.1):149-157.

Marinkelle, C. J. \& Cadena, A. 1972. Notes on bats new to the fauna of Colombia. Mammalia 36:49-58.

Martins, A. C. M.; Bernard, E. \& Gregorin, R. 2006. Inventários biológicos rápidos de morcegos (Mammalia, Chiroptera) em três unidades de conservação do Amapá, Brasil. Revista Brasileira de Zoologia 23(4):1175-1184.

McCarthy, T. J. 1982. Bat records from the Caribbean lowlands of El Peten, Guatemala. Journal of Mammalogy 63(4): 683-685.

1987. Distributional records of bats from the caribbean lowlands of Belize and adjacent Guatemala and Mexico. In: Patterson, B. D. \& Timm, R. M. eds. Studies in Neotropical Mammalogy: essays in honor of Philip Hershkovitz. Fieldiana Zoology 39. p.137-162.

Miranda-Ribeiro, A. 1914. Mammiferos. Publicações e Comunicações das Linhas Telegráficas e Estratigráficas do Mato-Grosso ao Amazonas 17 (anexo 5):1-49. (Historia Natural - Zoologia).

Miretski, M. 2003. Morcegos do Estado do Paraná, Brasil (Mammalia, Chiroptera): riqueza de espécies, distribuição e síntese do conhecimento atual. Papéis Avulsos de Zoologia 43(6): 101-138.

Molina, C.; García, C. \& Ochoa, G. J. 1995. First record of Mimon bennettii (Chiroptera: Phyllostomidae) for Venezuela. Mammalia 59(2):263-265.

Montenegro, O. L. \& Romero-Ruiz, M. 1999. Murciélagos del sector sur de la serranía de Chiribiquete, Caquetá, Colombia. Revista da Academia Colombiana de Ciências Exatas, Fisicas y Natural 23 (supl. Esp.):641-649.
Ortega, J. \& Arita, H. T. 1997. Mimon bennettii. Mammalian Species 549:1-4.

ReID, F. A. 1997. A field guide to the mammals of Central America and southeast Mexico. New York, Oxford University. 334p.

Reis, N. R dos; Peracchi, A. L. \& Sekiama, M. L. 1999. Morcegos da Fazenda Monte Alegre, Telêmaco Borba, Paraná (Mammalia, Chiroptera). Revista Brasileira de Zoologia 16(2):501-505.

SAnborn, C. C. 1941. Descriptions and records of Neotropical bats. Field Museum of Natural History, Zoology 27:371-387.

Schaldach, A. 1964. Notas breves sobre algunos mamíferos de sur de Mexico. Anales Instituto de Biología 35:129-137.

Simmons, N. B. 2005. Order Chiroptera. In: Wilson, D. E. \& ReEder, D. M. eds. Mammal species of the world: a taxonomic and geographic reference. 3ed. v.1. Baltimore, Johns Hopkins University. xxxv $+743 p$.

Simmons, N. B. \& Voss, R. S. 1998. The mammals of Paracou, French Guiana: a Neotropical lowland rainforest fauna part 1. Bats. Bulletin of the American Museum of Natural History 237:1-218.

Smith, P. G. \& Kerry, S. M. 1996. The Iwokrama Rain Forest Programme for sustainable development: how much of Guyana's bat (Chiroptera) diversity does it encompasse? Biodiversity and Conservation 5:921-942.

Swanepoel, P. \& Genowyas, H. H. 1979. Morphometrics. In Baker, R. J.; Jones, J. K., Jr. \& Carter, D. C. eds. Biology of bats of the New World family Phyllostomatidae, part III. Special Publications Texas Tech University 16. p.13-106.

Thomas, O. 1902. Notes on the phyllostomatous genera Mimon and Tonatia. Annals and Magazine of the Natural History 10(7):53-54.

VALDEZ, R. \& LA VAL, R. K. 1971. Records of bats from Honduras and Nicaragua. Journal of Mammalogy 52(1):247-250.

Vieira, C. O. C. 1942. Ensaio monográfico dos quirópteros do Brasil. Arquivos de Zoologia 3(8):219-471.

Winkelmann, J. R. 1962. Additional records of Mimon cozumelae. Journal of Mammalogy 43(1):112.

Zar, J. H. 1999. Biostatistical Analysis. New Jersey, Prentice Hall. 4th ed. 683p + app. 